\title{
Effect of Fungicide Applications Scheduled to Control Gummy Stem Blight on Yield and Quality of Watermelon Fruit
}

\author{
Anthony P. Keinath, Associate Professor, Department of Plant Pathology and Physiology, Clemson University, \\ Coastal Research and Education Center, Charleston, SC 29414-5333
}

\begin{abstract}
Keinath, A. P. 2001. Effect of fungicide applications scheduled to control gummy stem blight on yield and quality of watermelon fruit. Plant Dis. 85:53-58.

Yield and quality reductions in watermelon infected with Didymella bryoniae may be attributed to reduced number or weight of fruit, sunburned fruit, fruit rot, or low sugar content due to gummy stem blight on foliage and black rot on fruit. Number, weight, soluble solids content, and external appearance of fruit were determined in four experiments conducted in fall 1996 and 1997 and spring 1997 and 1998. Severity of gummy stem blight was varied by applying no fungicide, mancozeb, or chlorothalonil according to different schedules. In the fall, when disease severity was high, total fruit weight, percent marketable fruit, and soluble solids content were lower and percent fruit with black rot was higher in nonsprayed than in sprayed treatments. Fungicide applications did not affect total fruit weight, soluble solids content, or black rot in the spring, when disease severity was moderate to low. Percent sunburned fruit was greater in treatments sprayed every 14 days than in those sprayed weekly. In fall experiments, the number of healthy, unblemished fruit increased linearly as the number of fungicide applications was increased from zero to nine per season. Yield losses in watermelon to gummy stem blight and black rot resulted primarily from a reduction in total fruit weight and an increase in number of diseased and sunburned fruit.
\end{abstract}

Additional keyword: Citrullus lanatus

Yield losses in watermelon (Citrullus lanatus (Thunb.) Matsum. \& Nikai) due to Didymella bryoniae (Auersw.) Rehm, the causal agent of gummy stem blight on foliage and black rot on fruit, average $>40 \%$ with high inoculum levels and conducive environmental conditions (12). Gummy stem blight and black rot may lower watermelon yield by reducing number or weight of fruit or by increasing fruit rot or sunburning of fruit exposed to the sun by loss of foliage (12). Watermelon yields commonly are reported as weight of marketable fruit $(7-9,18,20)$. From previous studies, it was not possible to determine if the reduction in marketable weight due to gummy stem blight epidemics resulted from a decrease in the number of marketable melons, the weight of individual fruit, or other factors such as black rot and sunburn.

Yield losses in cucurbits can be great when disease epidemics begin during the

Corresponding author: A. P. Keinath

E-mail: tknth@clemson.edu

Technical Contribution No. 4600 of the South Carolina Agriculture and Forestry Research System, Clemson University, Clemson, SC. This project was supported with funds from the Southern Region Pesticide Impact Assessment Program and Hatch Project SC01628.

Accepted for publication 15 September 2000.

Publication no. D-2000-1031-01R

(c) 2001 The American Phytopathological Society early reproductive phase of crop growth. Epidemics of gummy stem blight that exceeded $50 \%$ diseased leaf area before the first watermelon fruit were mature significantly reduced marketable weight (11). Early onset of anthracnose significantly reduced yields of watermelon (1) and pickling cucumber (30) compared with epidemics that began later in the growing season. On cantaloupe, the time that Alternaria leaf blight severity remained $\leq 1 \%$ was linearly related to the yield loss percentage based on total fruit weight (19). Alternatively, a rapid increase in disease incidence or severity during the later reproductive period can halt additional fruit set and expansion and also lead to fields being abandoned before harvest. In June 1991, when gummy stem blight was especially severe on watermelon in South Carolina, over $15 \%$ of the watermelon acreage was never harvested (28). Furthermore, when cucurbit vines are severely affected with leaf blights, such as gummy stem blight, fruit mature but may not expand to full size (25). Hence, overall tonnage is reduced and some fruit do not reach the minimum marketable size (14). The ideal weight for watermelons in the current United States market is 8.2 to $10.0 \mathrm{~kg}$ each, and diploid fruit of $<5.4$ to $6.4 \mathrm{~kg}$ are not marketable, depending on the market in a given season or year (4).

Watermelon fruit are not as susceptible to black rot as are fruit of Cucurbita spp. $(33,36)$. However, watermelon fruit with black rot must be culled and, in extreme cases, may rot before harvest $(3,36)$. Black rot incidence of $17 \%$ has been reported on watermelon both at harvest (14) and after $\leq 3$ weeks in storage (5). In the Caribbean, watermelon fruit severely affected with black rot had "poor quality" flesh (3). Losses of cantaloupe fruit to black rot can be up to $100 \%$ when cool, wet weather favors the pathogen $(24,35)$.

The main determinant of watermelon flesh quality is high total sugar content (27). Current United States Department of Agriculture (USDA) standards call for a minimum $10 \%$ soluble solids in watermelon fruit having "very good internal quality" (2). Soluble solids content of watermelon fruit was reduced greatly by downy mildew on the foliage (26). In another study, watermelon fruit from plants which were not sprayed and became infected with both downy mildew and gummy stem blight had soluble solids contents that were $10 \%$ lower than fruit from plants sprayed weekly (34). However, because two diseases were present, it was not possible to determine how much of the reduction in sugar content was due to gummy stem blight alone.

Amount of sunburning on watermelon fruit is another determinant of fruit quality. Severe sunburn leads to sun scald, characterized by extensive tan- or salmon-colored damaged areas on the rind. The USDA standards for No. 1 grade watermelons allow for only $58 \mathrm{~cm}^{2}$ of sunburned area on an 11.3-kg melon and no sun scald (2). Sunburning of watermelon fruit close to maturity occurs periodically in the southeastern United States and can reduce marketable yields $(16,23)$. Defoliation of vines by foliar pathogens exposes fruit to high temperature and light intensity and can increase the number of fruit graded as unmarketable because of sunburn (23).

The objective of this study was to determine the effect of fungicide application schedules on watermelon yield components and quality indicators as a result of controlling gummy stem blight and black rot. Details of the application schedules and their effect on gummy stem blight severity and weight of marketable fruit have been published previously (10).

\section{MATERIALS AND METHODS}

Four experiments were conducted, one each in the fall of 1996 and 1997 and the spring of 1997 and 1998, at Clemson Uni- 
versity's Coastal Research and Education Center, Charleston, SC. The soil was a Yonges loamy fine sand (fine-loamy, mixed, thermic, Typic Albaquults), $\mathrm{pH} 6.1$ to 6.3 except in spring 1997, when the $\mathrm{pH}$ was 5.6 and dolomitic lime was applied at $1,680 \mathrm{~kg} / \mathrm{ha}$. Commercial production practices were followed (4) and details of the cultural practices used have been reported previously $(10,11,14,15)$. Briefly, the rye cover crop was mowed and the fields were disced thrice before each experiment, except in fall 1997, when the field was disced twice after being fallow in the spring season. Raised beds were shaped $0.9 \mathrm{~m}$ wide on 1.8-m centers and 15-0-12.5 (N-P-K) fertilizer at 560 to $900 \mathrm{~kg} / \mathrm{ha}$, based on soil fertility analyses, was banded in the rows. Raised beds were then covered with whiteon-black polyethylene mulch in the fall or black mulch in the spring. Seedlings of the diploid watermelon cultivar Royal Star, susceptible to gummy stem blight (13), with two fully expanded true leaves, were transplanted into every other row and spaced $0.9 \mathrm{~m}$ apart within rows on 5 August 1996, 27 March 1997, 6 August 1997, and 1 April 1998. A side dressing of 15-0-12.5 (N-P-K) fertilizer at $224 \mathrm{~kg} / \mathrm{ha}$ was applied in 1996 and 1997; 10-4.4-8.3 (N-P-K) at $280 \mathrm{~kg} / \mathrm{ha}$ was used in 1998. Herbicides, insecticides, nematicides, and overhead irrigation were applied as needed (4). Copper hydroxide (Kocide DF, $0.90 \mathrm{~kg}$ a.i./ha) was applied to all plots as a preventative treatment against watermelon fruit blotch, once in the spring of 1997 and thrice in 1998. To control powdery mildew, triadimefon (Bayleton 50DF, $0.14 \mathrm{~kg}$ a.i./ha) was applied to all plots once in 1996, thrice in the spring of 1997, and once in 1998; thiophanate-methyl (Topsin-M, $0.39 \mathrm{~kg}$ a.i./ha) also was applied once in 1998. D. bryoniae is insensitive to triadimefon and over half of the isolates collected from South Carolina were insensitive to thiophanate-methyl (17).

The design for all experiments was a split plot with five replications. Plots were single rows, $15.2 \mathrm{~m}$ long with $1.8 \mathrm{~m}$ of nonsprayed vines between plots within rows. Mancozeb and chlorothalonil were the treatments assigned to whole plots, and seven to nine application schedules plus a nonsprayed treatment were the split plot treatments within each whole plot. Mancozeb (Manzate 200DF) and chlorothalonil (Bravo Weather Stik) were both applied at $2.52 \mathrm{~kg}$ a.i./ha with a tractor-mounted hydraulic boom sprayer. Details of application schedules have been reported previously $(10,11,14,15)$. Between 3 and 10 fungicide applications were made in the different treatments, based on different spray initiation and termination times and frequencies of application (Table 1). Spray schedules initiated at anthesis began 7 to 21 days earlier than schedules initiated at disease detection, except in the fall of 1996, when disease appeared 9 days after transplanting, well before anthesis at 17 days after transplanting (10). For the Melcast treatment, fungicides were applied whenever the environmental favorability indices totaled $35(20,21)$.

At harvest, all fruit were weighed individually and graded on appearance according to USDA standards for watermelon (2). Melons weighing $>6.35 \mathrm{~kg}$ in US No. 1 and No. 2 grades were considered marketable. Unmarketable small melons weighed $<5.4 \mathrm{~kg}$, extra-small weighed 5.44 to $6.35 \mathrm{~kg}$, small weighed 6.36 to $8.16 \mathrm{~kg}$, medium weighed 8.17 to $9.98 \mathrm{~kg}$, and large weighed $\geq 9.99 \mathrm{~kg}$. Fruit that were of marketable size were classified as unmarketable if they had the following quality defects: sunburn on $\geq 58$ or $\geq 77 \mathrm{~cm}^{2}$ on an $11.3-\mathrm{kg}$ melon in grades No. 1 or No. 2 , respectively; deformed shape; black rot, anthracnose fruit rot, or other fruit rots (primarily Southern blight in spring 1998 and Fusarium spp. in other experiments); rind damage from cucumber beetle feeding, damage from animals (primarily raccoons and crows), or scars longer than 5 $\mathrm{cm}$ (2). For each fungicide application, a price of $\$ 25.82 /$ ha was used for mancozeb and $\$ 46.51 /$ ha for chlorothalonil, labor was estimated at \$4.13/ha, and equipment and operation costs were estimated at $\$ 2.32 / \mathrm{ha}$ (12). Variable preharvest production costs (in addition to fungicide applications) were calculated to be $\$ 974 /$ ha. Marketable fruit price was $\$ 0.285 / \mathrm{kg}$ (mean of $\$ 0.37 / \mathrm{kg}$ in 1996 and \$0.20/kg in 1997).

Analysis of variance was performed with PROC GLM of SAS (version 6.12; SAS Institute, Inc., Cary, NC). Before analysis, data were tested for homogeneity of variance and normality. When there was no effect of fungicide and fungicide-treatment interaction, means of the spray schedule treatments were calculated across the two fungicides and fungicide means were calculated across all spray treatments. In addition to the Waller-Duncan $k$-ratio $t$ test to separate all treatment means, preplanned sets of single-degree-of-freedom contrasts were used to compare the nonsprayed control with the average of all sprayed treatments and to compare spray intervals with each other (10). Because of the low number of melons that were diseased or sunburned in some experiments, data sets with homogenous variances were pooled by season across years.

\section{RESULTS}

Fungicide applications resulted in greater total fruit weight $(\mathrm{Mg} / \mathrm{ha})$ than in the nonsprayed control in fall experiments but not in spring experiments (Tables 2 and 3 ). In each fall experiment, the nonsprayed treatment had lower weight of total fruit than the mean of all sprayed treatments (Table 2). In fall 1997, fungicide applications beginning at anthesis or disease detection increased total fruit weight over the nonsprayed control. The only two exceptions were Melcast and the 10-day interval begun at disease detection. In fall 1996, only the 7-day treatment that was sprayed from anthesis to first harvest had greater fruit weight than the nonsprayed treatment. In addition, spraying every 7 days increased total weight by $3.8 \mathrm{Mg} / \mathrm{ha}$ over spraying every 14 days (Table 2 ). In each spring experiment, total fruit weight was greater than in the fall, but there were no significant differences among treatments (Table 3). Yield of total fruit with the two fungicides did not differ in any season and there were no interactions between application schedule and fungicide in any experiment.

Table 1. Number of applications of chlorothalonil or mancozeb made to watermelon according to different schedules in four experiments

\begin{tabular}{|c|c|c|c|c|c|c|}
\hline \multicolumn{3}{|l|}{ Fungicide schedule } & \multicolumn{4}{|c|}{ Number of fungicide applications ${ }^{\mathrm{z}}$} \\
\hline Interval (days) & Initiation & Termination & Fall 1996 & Spring 1997 & Fall 1997 & Spring 1998 \\
\hline Nonsprayed control & & & 0 & 0 & 0 & 0 \\
\hline 7 & Anthesis & First harvest & 7 & 7 & 7 & 8 \\
\hline 7 & Anthesis & Last harvest & 8 & 10 & nd & nd \\
\hline 7 & Detection & First harvest & 8 & 5 & 6 & 5 \\
\hline 7 & Detection & Last harvest & 9 & 8 & nd & 6 \\
\hline 10 & Anthesis & First harvest & nd & nd & 5 & 6 \\
\hline 10 & Detection & First harvest & nd & nd & 4 & 4 \\
\hline 14 & Anthesis & First harvest & 4 & 4 & 4 & 4 \\
\hline 14 & Anthesis & Last harvest & 4 & 5 & nd & nd \\
\hline 14 & Detection & First harvest & 4 & 3 & 3 & 3 \\
\hline 14 & Detection & Last harvest & 5 & 4 & nd & 3 \\
\hline Melcast & $\ldots$ & $\ldots$ & 4 & 4 & 6 & 5 \\
\hline
\end{tabular}

${ }^{\mathrm{z}} \mathrm{nd}=$ Not done in this season. 
The mean number of total fruit harvested was very similar in fall 1996, spring 1997, and fall 1997 with 3,766, 3,586, and 3,766 fruit/ha, respectively, averaged across fungicides and schedules. In spring 1998, 4,662 fruit/ha were harvested. Averaged across the two fungicides in both fall experiments, the total number of healthy, unblemished fruit of all sizes increased linearly as the number of fungicide applications per season increased $\left(R^{2}=0.53, P\right.$ $=0.0006$; Fig. 1). Healthy fruit number increased from an average of 8.7 fruit per $15.2-\mathrm{m}$ row in the nonsprayed treatment to 12.5 fruit per $15.2-\mathrm{m}$ row with nine fungicide applications, an increase of $44 \%$. Numbers of total fruit were not affected by fungicide applications in spring experiments. Mean weight of individual fruit in fall $1997(5.3 \mathrm{~kg})$, spring $1997(9.4 \mathrm{~kg})$, and spring $1998(9.9 \mathrm{~kg})$ did not vary significantly among fungicide schedules or between fungicides (data not shown). In fall 1996, mean fruit weight $(3.9 \mathrm{~kg})$ was greater in the four treatments sprayed weekly than in the four treatments sprayed biweekly (3.5 kg; single-degree-of-freedom contrast, $P=0.01$ ).

The percentage of fruit that were of marketable size and quality $(>6.35 \mathrm{~kg}$ in US No. 1 and No. 2 grades), based on the total weight of fruit harvested, was lower in fall experiments (23 and 39\% in 1996 and 1997, respectively) than in spring experiments (57 and 79\% in 1997 and 1998, respectively). Averaged across fungicides and both fall experiments, percent marketable fruit was greater $(33.4 \%)$ in sprayed treatments than in the nonsprayed treatment $\quad(23.7 \%$; single-degree-offreedom contrast, $P=0.02$ ). In fall 1996, 7-day treatments produced more marketable fruit $(28.5 \%)$ than did 14-day treatments $(19.6 \% ; P=0.01)$, averaged across fungicides. In spring 1998, significant differences were observed between several application schedules, but the range among schedules was narrow (75 to $85 \%$ marketable fruit; data not shown).
In spring 1998, weight of individual fruit of marketable size and quality was slightly greater in sprayed treatments $(10.5 \mathrm{~kg}$ averaged across fungicides and nine schedules) than in the nonsprayed treatment $(10.0 \mathrm{~kg} ; P=0.03)$. In fall 1996 , mean weight $(7.9 \mathrm{~kg})$ of individual marketable fruit was greater in the four treatments sprayed weekly than in the four treatments sprayed biweekly $(7.4 \mathrm{~kg} ; P=0.004)$. Mean weight of individual marketable fruit was $10.2 \mathrm{~kg}$ in spring 1997 and $8.00 \mathrm{~kg}$ in fall 1997 and did not differ among any treatments in these two experiments.

Percentage of watermelon fruit with sufficient sunburned area to be culled $(\geq 77$ $\mathrm{cm}^{2}$ on an 11.3-kg fruit; 2) was lowest in fall 1996 and highest in spring 1997 (Table 4). In fall 1996 and spring 1997, percent sunburned fruit was significantly greater in treatments sprayed every 14 days than in treatments sprayed every 7 days. Likewise, in fall 1997, percent sunburned fruit was significantly greater in the nonsprayed control and in treatments sprayed every 10

Table 2. Mean weight (Mg/ha) of all watermelon fruit harvested (marketable plus cull) across different fungicide application treatments of chlorothalonil or mancozeb in fall experiments ${ }^{\mathrm{w}}$

\begin{tabular}{|c|c|c|c|c|c|c|c|c|c|c|c|c|c|c|}
\hline \multirow[b]{3}{*}{ Treatment } & \multicolumn{7}{|c|}{ Fall 1996} & \multicolumn{7}{|c|}{ Fall 1997} \\
\hline & \multicolumn{2}{|c|}{ Mancozeb } & \multicolumn{2}{|c|}{ Chlorothalonil } & \multicolumn{3}{|c|}{ Fungicide means ${ }^{x}$} & \multicolumn{2}{|c|}{ Mancozeb } & \multicolumn{2}{|c|}{ Chlorothalonil } & \multicolumn{3}{|c|}{ Fungicide means ${ }^{x}$} \\
\hline & Mean & $\mathbf{S E}$ & Mean & SE & Mean & $F^{\mathbf{y}}$ & Prob. ${ }^{y}$ & Mean & SE & Mean & SE & Mean & $F^{\mathrm{y}}$ & Prob. $^{y}$ \\
\hline Nonsprayed & 25.0 & 4.9 & 17.2 & 3.2 & 21.1 & 4.16 & 0.04 & 22.0 & 3.9 & 31.0 & 1.7 & 26.5 & 10.0 & 0.003 \\
\hline All sprayed & 25.9 & 1.2 & 24.2 & 1.4 & 25.0 & 0.72 & 0.40 & 32.9 & 2.0 & 36.6 & 2.2 & 34.7 & 0.97 & 0.37 \\
\hline Melcast & 23.6 & 2.7 & 23.5 & 2.8 & 23.6 & & $\ldots$ & 27.4 & 3.7 & 37.5 & 5.0 & 32.5 & & $\ldots$ \\
\hline 7 -day & 27.2 & 2.0 & 27.0 & 2.5 & $27.1 * *$ & 8.60 & 0.005 & 36.2 & 3.7 & 37.1 & 3.1 & $36.3 * *$ & $0.76^{z}$ & $0.39^{\mathrm{z}}$ \\
\hline 10-day & $\ldots$ & $\ldots$ & $\ldots$ & $\ldots$ & & $\ldots$ & $\ldots$ & 28.1 & 1.6 & 35.0 & 3.0 & 31.6 & 5.56 & 0.02 \\
\hline 14-day & 25.1 & 1.6 & 21.6 & 1.7 & 23.3 & & $\ldots$ & 37.4 & 1.8 & 37.2 & 2.2 & $37.3^{* * *}$ & & \\
\hline Anthesis & 26.3 & 2.0 & 24.3 & 2.3 & $25.3 *$ & 0.01 & 0.94 & 33.5 & 2.0 & 39.6 & 3.0 & $36.3^{* * *}$ & 1.70 & 0.20 \\
\hline Detection & 26.0 & 1.6 & 24.3 & 2.2 & $25.2^{*}$ & & & 34.2 & 2.6 & 33.3 & 1.7 & $33.7 * *$ & $\ldots$ & $\ldots$ \\
\hline First harvest & 26.3 & 2.0 & 26.3 & 2.1 & $26.3^{* *}$ & 2.89 & 0.09 & $\ldots$ & $\ldots$ & $\ldots$ & $\ldots$ & $\ldots$ & $\ldots$ & $\ldots$ \\
\hline Last harvest & 26.0 & 1.7 & 22.3 & 2.3 & 24.1 & $\ldots$ & $\ldots$ & $\ldots$ & $\ldots$ & $\ldots$ & $\ldots$ & $\ldots$ & $\ldots$ & $\ldots$ \\
\hline
\end{tabular}

${ }^{\mathrm{w}} \ldots$. = Treatment not done; means followed by $*, * *$, or $* * *$ differ from the nonsprayed control treatment at $P \leq 0.05,0.01$, and 0.001 , respectively, according to preplanned single-degree-of-freedom contrasts.

$x$ No fungicide-treatment interaction.

${ }^{\text {y }} F$ value and probability of a greater $F$ value for the single-degree-of-freedom orthogonal contrast of the treatment mean with the mean immediately following.

${ }^{\mathrm{z}}$ Single-degree-of-freedom orthogonal contrast of 7-day applications with the mean of 10- and 14-day applications.

Table 3. Mean weight $(\mathrm{Mg} / \mathrm{ha})$ of all watermelon fruit harvested (marketable plus cull) across different fungicide application treatments of chlorothalonil or mancozeb in spring experiments ${ }^{\mathrm{w}}$

\begin{tabular}{|c|c|c|c|c|c|c|c|c|c|c|c|c|c|c|}
\hline \multirow[b]{3}{*}{ Treatment } & \multicolumn{7}{|c|}{ Spring 1997} & \multicolumn{7}{|c|}{ Spring 1998} \\
\hline & \multicolumn{2}{|c|}{ Mancozeb } & \multicolumn{2}{|c|}{ Chlorothalonil } & \multicolumn{3}{|c|}{ Fungicide means ${ }^{x}$} & \multicolumn{2}{|c|}{ Mancozeb } & \multicolumn{2}{|c|}{ Chlorothalonil } & \multicolumn{3}{|c|}{ Fungicide means $^{x}$} \\
\hline & Mean & SE & Mean & $\mathrm{SE}$ & Mean & $F^{\mathbf{y}}$ & Prob.y & Mean & SE & Mean & SE & Mean & $F^{y}$ & Prob.y \\
\hline Nonsprayed & 63.1 & 3.7 & 56.9 & 3.2 & 60.0 & 0.00 & 0.99 & 77.3 & 7.3 & 78.4 & 9.6 & 77.9 & 0.98 & 0.33 \\
\hline All sprayed & 63.7 & 1.8 & 56.1 & 2.1 & 59.9 & 0.22 & 0.64 & 81.6 & 2.0 & 85.0 & 2.7 & 83.3 & 0.30 & 0.58 \\
\hline Melcast & 68.2 & 6.3 & 55.0 & 2.6 & 61.6 & & & 81.9 & 4.9 & 79.2 & 4.0 & 80.6 & & \\
\hline 7-day & 62.7 & 2.7 & 56.3 & 3.7 & 59.5 & 0.03 & 0.87 & 81.6 & 4.0 & 82.9 & 4.4 & 82.3 & $1.18^{\mathrm{z}}$ & $0.28^{\mathrm{z}}$ \\
\hline 10-day & & $\ldots$ & 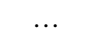 & 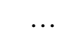 & & $\ldots$ & $\ldots$ & 75.7 & 4.9 & 85.2 & 3.9 & 80.5 & 1.37 & 0.25 \\
\hline 14-day & 63.7 & 2.8 & 56.2 & 2.8 & 60.0 & & & 85.3 & 2.8 & 89.2 & 7.0 & 87.3 & & \\
\hline Anthesis & 60.2 & 2.1 & 55.1 & 2.9 & 57.7 & 2.27 & 0.14 & 78.6 & 3.0 & 77.3 & 5.9 & 78.0 & 2.22 & 0.14 \\
\hline Detection & 66.2 & 3.2 & 57.4 & 3.7 & 61.8 & & & 87.8 & 3.0 & 91.0 & 3.1 & 89.4 & & \\
\hline First harvest & 60.7 & 2.4 & 54.0 & 2.8 & 57.4 & 3.02 & 0.09 & 80.5 & 2.5 & 83.4 & 2.9 & 82.0 & 0.02 & 0.88 \\
\hline Last harvest & 65.7 & 3.0 & 58.5 & 3.7 & 62.1 & $\ldots$ & $\ldots$ & 85.3 & 3.2 & 90.8 & 6.8 & 88.1 & $\ldots$ & $\ldots$ \\
\hline
\end{tabular}

w... = Treatment not done.

${ }^{x}$ No fungicide-treatment interaction.

${ }^{\text {y }} F$ value and probability of a greater $F$ value for the single-degree-of-freedom orthogonal contrast of the treatment mean with the mean immediately following.

${ }^{\mathrm{z}}$ Single-degree-of-freedom orthogonal contrast of 7-day applications with the mean of 10- and 14-day applications. 
or 14 days than in the 7-day treatment. The Melcast treatment significantly reduced percent sunburned fruit in fall 1997 and spring 1998 compared with the nonsprayed control. However, initiation and termination times generally did not affect percent sunburned fruit. The two fungicides differed in both spring experiments: chlorothalonil treatments overall had a lower percentage of sunburned fruit in spring 1997 but a higher percentage in spring 1998 (Table 4).

Averaged across fungicides and years for fall experiments, the percentage of fruit with black rot symptoms was significantly higher (13.6\% of all fruit; $P=0.02)$ in the nonsprayed treatment compared with the mean of all sprayed treatments $(9.5 \%$;
Table 5). Spraying every 7 days, starting when gummy stem blight appeared on the foliage, reduced percent black rot compared with the nonsprayed control. In spring experiments, percentage of fruit with black rot was lower than in fall experiments (2.0 and 1.3\% in spring 1997 and 1998, respectively) and was not affected by fungicide applications (data not shown). Other fruit rots, such as anthracnose, Southern blight, and Fusarium fruit rots, were not prevalent enough to differ among treatments in any experiment.

In fall experiments, applying mancozeb or chlorothalonil every 7 days or according to Melcast slightly but significantly increased soluble solids content over the nonsprayed control (Table 5). In addition,

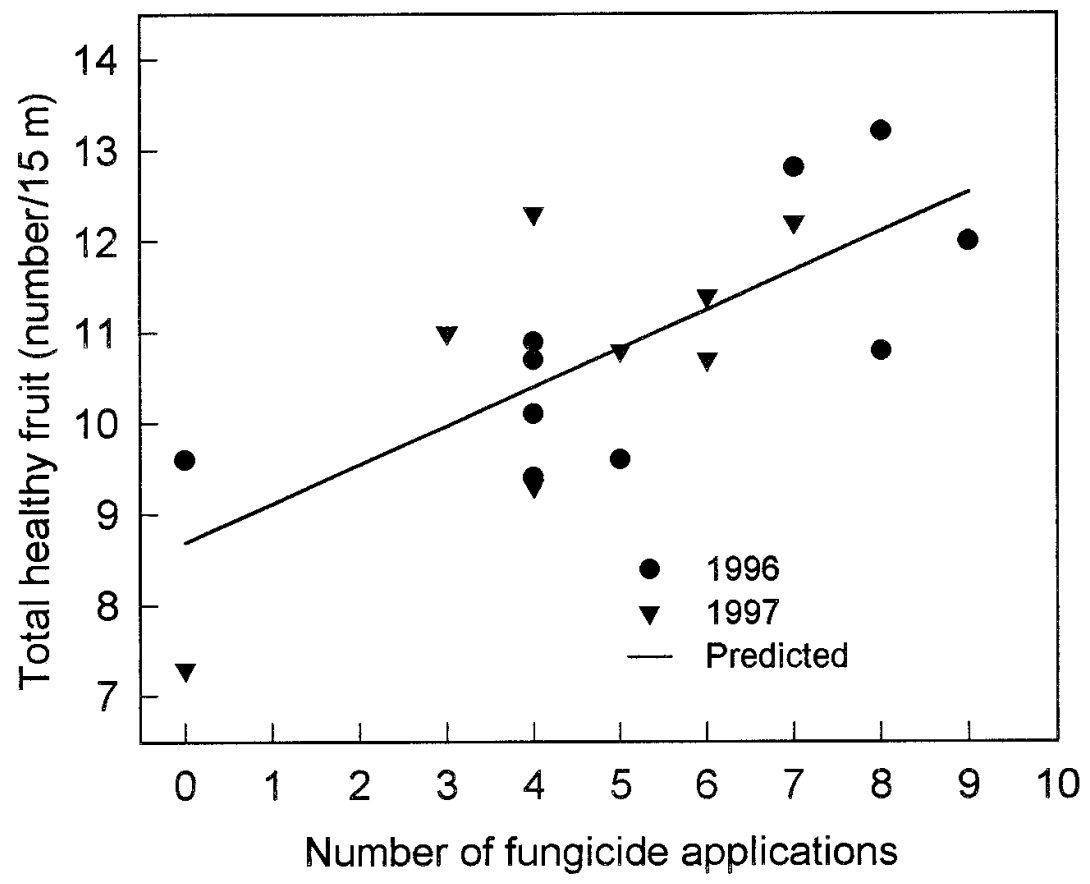

Fig. 1. Relationship between the total number of fungicide applications made in fall experiments and the number of healthy, unblemished fruit harvested. Data points are means of five replications across mancozeb and chlorothalonil treatments.

when sprays began after foliar symptoms of gummy stem blight were detected, spraying every 7 days was more effective than spraying every 14 days. Likewise, mean percent fruit with high sugar content $(>10 \%$ Brix; 2) was greater $(60.5 \%)$ with 7-day application intervals than with 14day intervals (46.5\%; single-degree-offreedom contrast, $P=0.03$; Table 5). Soluble solids contents were higher in spring experiments (11.6\% in 1997 and $11.1 \%$ in 1998, averaged across fungicides and schedules) than in fall experiments, but did not differ among application schedules (data not shown). Soluble solids content did not differ between mancozeb or chlorothalonil in any experiment.

Fungicide applications increased yields only in fall experiments; therefore, cost of fungicide applications, crop value, and income above variable preharvest costs of production were calculated across the 1996 and 1997 fall experiments. Fungicide application costs ranged from a low of $12 \%$ to a high of $38 \%$ of the remaining variable preharvest production costs of $\$ 974 / \mathrm{ha}$. Crop value and income for the application schedules differed between the two fungicides (fungicide-treatment interaction, $F$ test significant at $P=0.058$ and 0.056 for value and income, respectively; Table 6). Sprays beginning at anthesis and continuing every 7 days until first harvest significantly increased crop value and income over the nonsprayed control with both fungicides. Melcast used with chlorothalonil, but not mancozeb, also significantly increased crop value and income.

\section{DISCUSSION}

With no fungicide applications, D. bryoniae reduced total fruit weight, soluble solids content of fruit, and percentage of fruit with soluble solids $>10 \%$ Brix. Percentage of fruit with black rot also was greater with no fungicide applications than with fungicides. Increasing the number of fungicide applications improved yields by

Table 4. Percent sunburned watermelon fruit averaged across different fungicide application treatments of chlorothalonil or mancozeb in four experiments $^{\mathrm{x}}$

\begin{tabular}{|c|c|c|c|c|c|c|c|c|c|c|c|c|c|c|c|c|}
\hline \multirow[b]{2}{*}{ Treatment } & \multicolumn{4}{|c|}{ Fall 1996y } & \multicolumn{4}{|c|}{ Fall 1997y } & \multicolumn{4}{|c|}{ Spring 1997} & \multicolumn{4}{|c|}{ Spring $1998^{y}$} \\
\hline & Mean & SE & $F^{\mathbf{z}}$ & Prob. $^{z}$ & Mean & SE & $F$ & Prob. & Mean & SE & $F$ & Prob. & Mean & SE & $F$ & Prob. \\
\hline Nonsprayed & 4.9 & 2.9 & 0.48 & 0.49 & 16.8 & 5.0 & 8.19 & 0.006 & 20.9 & 4.3 & 0.02 & 0.89 & 9.5 & 2.5 & 0.05 & 0.82 \\
\hline All sprayed & 5.6 & 0.8 & 0.05 & 0.82 & 7.7 & 1.3 & 2.65 & 0.11 & 21.3 & 1.3 & 1.58 & 0.21 & 8.1 & 0.8 & 7.67 & 0.007 \\
\hline Melcast & 4.9 & 1.8 & $\ldots$ & & $3.6 * *$ & 1.8 & $\ldots$ & $\ldots$ & 25.2 & 4.0 & $\ldots$ & $\ldots$ & $2.8^{*}$ & 1.0 & 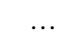 & $\ldots$ \\
\hline 7-day & 3.5 & 0.8 & 8.29 & 0.005 & $5.3 * *$ & 1.9 & 4.16 & 0.05 & 17.5 & 1.7 & 7.76 & 0.007 & 11.0 & 1.7 & 0.19 & 0.66 \\
\hline 10-day & $\ldots$ & $\ldots$ & $\ldots$ & $\ldots$ & $9.6^{*}$ & 3.1 & 0.35 & 0.56 & $\ldots$ & $\ldots$ & $\ldots$ & $\ldots$ & 7.7 & 1.6 & 0.03 & 0.86 \\
\hline 14-day & 8.0 & 1.5 & . & & 10.3 & 2.6 & & & 24.2 & 2.0 & & 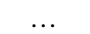 & 7.2 & 1.2 & & \\
\hline Anthesis & 5.5 & 1.7 & 0.32 & 0.57 & $8.6^{*}$ & 2.1 & 0.10 & 0.76 & 20.4 & 2.7 & 0.17 & 0.68 & 7.6 & 1.6 & 3.75 & 0.06 \\
\hline Detection & 5.9 & 1.3 & & & $8.2 * *$ & 2.1 & $\ldots$ & $\ldots$ & 21.3 & 1.9 & & & 9.4 & 1.0 & & \\
\hline First harvest & 5.6 & 1.1 & 0.00 & 0.99 & $\ldots$ & $\ldots$ & $\ldots$ & $\ldots$ & 21.8 & 2.0 & 0.65 & 0.42 & 7.6 & 0.9 & 0.09 & 0.77 \\
\hline Last harvest & 5.9 & 1.4 & & & & $\ldots$ & & $\ldots$ & 19.9 & 1.8 & & & 10.0 & 1.7 & & \\
\hline Mancozeb & 6.9 & 1.1 & 1.24 & 0.33 & 5.7 & 1.2 & 2.98 & 0.15 & 26.1 & 1.5 & 22.56 & 0.009 & 5.6 & 0.7 & 18.59 & 0.01 \\
\hline Chlorothalonil & 4.4 & 1.1 & $\ldots$ & $\ldots$ & 12.0 & 3.2 & $\ldots$ & $\ldots$ & 16.5 & 1.8 & $\ldots$ & $\ldots$ & 10.5 & 1.3 & $\ldots$ & $\ldots$ \\
\hline
\end{tabular}

${ }^{\mathrm{x}}$ No fungicide-treatment interactions in any year; $\ldots=$ treatment not done; fungicide schedule means followed by $*$ or $* *$ differ from the nonsprayed control treatment at $P \leq 0.05$ and 0.01 , respectively, according to preplanned single-degree-of-freedom contrasts.

${ }^{y}$ Means were transformed with arcsine-square root before analysis of variance.

${ }^{\mathrm{z}} F$ value and probability of a greater $F$ value for the single-degree-of-freedom orthogonal contrast of the treatment mean with the mean immediately following. 
increasing the number of healthy, unblemished fruit by $44 \%$ with weekly sprays compared to no fungicide applications. Conversely, reducing fungicide inputs by spraying every 14 days rather than every 7 days reduced fruit quality, as measured by percent sunburned fruit, soluble solids content, and percentage of fruit with $>10 \%$ Brix. In another study, number of marketable fruit was increased by $115 \%$ with weekly fungicide applications compared with no fungicide (34). Postharvest black rot was almost three times higher on watermelon when only one application of fungicide was made in the field compared with three applications (5). Clearly, fungicides are an important tool to prevent or reduce yield and quality losses to gummy stem blight and black rot in watermelon production.

Fungicide applications at regular, frequent intervals to control gummy stem blight during the reproductive phase of watermelon growth, anthesis to first harvest, are important to protect yield and quality $(9,10,20,34)$. In most instances where fungicides affected yield, quality, or economics in the current study, the most important component of the fungicide schedule was the application frequency. More frequent applications also increased

Table 5. Percentage of watermelon fruit with black rot and soluble solids content of fruit as affected by different application schedules of chlorothalonil or mancozeb in fall 1996 and $1997^{x}$

\begin{tabular}{|c|c|c|c|c|}
\hline \multicolumn{2}{|c|}{ Fungicide schedule } & \multirow[b]{2}{*}{ Black rot $(\%)^{y}$} & \multirow[b]{2}{*}{ Brix (\%) } & \multirow[b]{2}{*}{ Fruit $(\%)>10 \%$ Brix } \\
\hline Interval (days) & Initiation & & & \\
\hline Nonsprayed control & & $13.6 \mathrm{a}$ & $9.3 \mathrm{c}$ & 37.2 \\
\hline 7 & Anthesis & $8.8 \mathrm{ab}$ & $9.9 \mathrm{ab}$ & 62.0 \\
\hline 7 & Detection & $7.2 \mathrm{~b}$ & $10.1 \mathrm{a}$ & 59.1 \\
\hline 14 & Anthesis & $8.4 \mathrm{ab}$ & $9.7 \mathrm{abc}$ & 49.6 \\
\hline 14 & Detection & $11.6 \mathrm{ab}$ & $9.4 \mathrm{bc}$ & 43.3 \\
\hline Melcast & $\ldots$ & $11.3 \mathrm{ab}$ & $9.9 \mathrm{ab}$ & 54.1 \\
\hline Min. sig. difference ${ }^{Z}$ & $\ldots$ & 5.3 & 0.56 & NS \\
\hline
\end{tabular}

${ }^{\mathrm{x}}$ Means for application schedules were calculated across mancozeb and chlorothalonil treatments, since there were no interactions among fungicide, schedule, or year. All applications were terminated at first harvest. Only application schedules included in both experiments are listed.

y Percentage of fruit, based on total number of fruit harvested, with symptoms of black rot.

${ }^{\mathrm{z}}$ Minimum significant difference; Waller-Duncan $k$-ratio $t$ test, $k=100$ (approximates $P=0.05$ ); schedule means within a column with the same letter are not significantly different; NS = means do not differ significantly. to the nonsprayed control, whereas mancozeb was not effective (24).

Percentage of fruit that sunburn is mainly related to periods of high temperature and intense solar radiation shortly before harvest (23). As expected, percentage of fruit with sunburn generally was higher in the spring than in the fall, based on prevailing air temperatures in coastal South Carolina during the fruit maturation period. However, loss of healthy foliage from fungal leaf pathogens increases the number and area of fruit exposed to sunlight, as seen in fall 1997, when the nonsprayed control had twice the percentage of sunburned fruit as the sprayed treatments. Percent sunburned fruit was higher in spring 1997, when final disease severity was $70 \%$ in nonsprayed plots, than in spring 1998, when final disease severity was $<50 \%$ (10). In addition, percent sunburned fruit was lower when protectant fungicides were applied every 7 days than every 14 days in three of the four experiments. Reduced disease severity observed with 7-day schedules was an indirect measure of the amount of the foliar canopy remaining to shade fruit $(10,16,23)$. Although chlorothalonil has a 0-day preharvest interval, the manufacturer cautions against applying it within 21 days of harvest during hot, sunny weather because of a risk of injuring mature fruit. Because of this risk of phytotoxicity, some growers are reluctant to use chlorothalonil as the primary fungicide on watermelon (10). However, no consistent differences in percent sunburned fruit were found between chlorothalonil and mancozeb in these experiments.

Fungicide applications made weekly or according to Melcast increased soluble solids content in watermelon fruit over no fungicide. Fungicide applications also increased the percentage of fruit with high soluble solids content $(>10 \%)$. In a recent report, fruit from nonsprayed plants with severe gummy stem blight also had significantly lower soluble solids content than fruit from fungicide-treated but diseased

Table 6. Cost of fungicide applications, value of marketable watermelon fruit, and income above variable production costs with different fungicide application schedules used in fall experiments in 1996 and $1997^{\mathrm{v}}$

\begin{tabular}{|c|c|c|c|c|c|c|c|}
\hline \multicolumn{2}{|c|}{ Fungicide schedule } & \multicolumn{3}{|c|}{ Mancozeb (\$/ha) } & \multicolumn{3}{|c|}{ Chlorothalonil (\$/ha) } \\
\hline Interval (days) & Initiation & Fungicide $\operatorname{cost}^{\mathrm{w}}$ & Value $^{\mathrm{x}}$ & Income $^{y}$ & Fungicide cost & Value & Income \\
\hline Nonsprayed control & $\ldots$ & 0 & $1,522 \mathrm{~b}$ & $548 \mathrm{~b}$ & 0 & $1,963 \mathrm{~d}$ & $989 \mathrm{c}$ \\
\hline 7 & Anthesis & 226 & $3,947 \mathrm{a}$ & $2,747 \mathrm{a}$ & 371 & $3,672 \mathrm{ab}$ & $2,327 \mathrm{ab}$ \\
\hline 7 & Detection & 226 & $3,507 \mathrm{ab}$ & $2,307 a b$ & 371 & $3,149 a b c$ & $1,804 \mathrm{abc}$ \\
\hline 14 & Anthesis & 129 & $3,490 a b$ & $2,387 \mathrm{ab}$ & 212 & $2,622 \mathrm{bcd}$ & $1,436 b c$ \\
\hline 14 & Detection & 113 & $3,469 a b$ & $2,382 \mathrm{ab}$ & 185 & $2,319 \mathrm{~cd}$ & $1,161 b c$ \\
\hline Melcast & $\ldots$ & 161 & $2,146 \mathrm{ab}$ & $1,011 \mathrm{ab}$ & 265 & 3,948 a & 2,709 a \\
\hline Min. sig. difference ${ }^{z}$ & $\ldots$ & $\ldots$ & 2,042 & 2,117 & $\ldots$ & 1,100 & 1,167 \\
\hline
\end{tabular}

${ }^{\mathrm{v}}$ All fungicide applications were terminated at first harvest.

${ }^{w}$ Sum of the costs for fungicide materials (\$25.82/ha for mancozeb and $\$ 46.51 /$ ha for chlorothalonil), labor (\$4.13/ha), and equipment and operation (\$2.32/ha) multiplied by the number of applications from Table 1 averaged across fall 1996 and 1997.

$\mathrm{x}$ Marketable fruit were assumed to have a value of $\$ 0.285 / \mathrm{kg}$ (mean of $\$ 0.37 / \mathrm{kg}$ in 1996 and $\$ 0.20 / \mathrm{kg}$ in 1997 ).

${ }^{y}$ Income above variable preharvest costs of production was calculated as crop value - fungicide cost - \$974/ha variable preharvest production costs.

${ }^{\mathrm{z}}$ Minimum significant difference; Waller-Duncan $k$-ratio $t$ test, $k=100$ (approximates $P=0.05$ ); schedule means within a column with the same letter are not significantly different. 
plants (7). Soluble solids content of cantaloupe fruit decreased linearly as Alternaria leaf blight increased (22), but no such quantitative relationship was found between gummy stem blight levels and watermelon yields or quality (data not shown). However, preserving healthy leaf tissue by applying fungicides weekly presumably increased the amount of sugars available for transport to watermelon fruit.

Percent marketable fruit in this study generally was within the range reported by Duthie et al. (6), who applied fungicides every 7 to 10 days. Percent marketable yield was relatively constant across application schedules, fungicides, and years; therefore, schedules that increased total yields increased marketable yields as well (10). In the fall, a weekly fungicide application beginning at anthesis was the only treatment that increased total yield, crop value, and income above variable preharvest production costs, even though this schedule had the highest fungicide application cost. Weekly applications that began at disease detection increased yield and value but did not increase income. Melcast scheduling did not significantly increase total yields, but it increased crop value and income when used with chlorothalonil. Chlorothalonil has been shown to adhere better than mancozeb to muskmelon foliage (29), and this attribute may have been important with the application intervals scheduled using Melcast. In spring 1997 and 1998, plots sprayed biweekly yielded as well as plots sprayed weekly and there was little return for the extra cost of weekly fungicide sprays, particularly with chlorothalonil. Yield loss in pickling cucumber due to anthracnose also was high on susceptible cultivars in the fall, but not in the spring, in North Carolina (30). Nevertheless, because gummy stem blight epidemics can progress extremely rapidly under rainy conditions late in the growing season, some growers may not be comfortable with an increased risk of a disease outbreak if they reduce fungicide applications $(9,10)$.

This study provides the first quantitative estimates for a wide range of yield components and quality standards that were reduced by $D$. bryoniae infection of watermelon. Future yield loss studies in watermelon can focus on components that were most affected by gummy stem blight, such as bulk weight and number of fruit, rather than weight or size of individual fruit, which were only slightly affected. Under the environmental conditions and inoculum levels that prevailed in the spring experiments, total yields were not significantly reduced at low to moderate disease levels (10). Additional work is needed to define and quantify the ability of watermelon plants to tolerate or compensate for a certain amount of foliage lost to gummy stem blight.

\section{ACKNOWLEDGMENTS}

I thank W. May III, V. DuBose, and K. Moore for technical assistance; R. X. Latin, Purdue University, for use of the Melcast disease forecaster; P. J. Rathwell, Clemson University for assistance with economic analysis; and J. A. Duthie, Oklahoma State University, for helpful discussions.

\section{LITERATURE CITED}

1. Amin, K. S., and Ullasa, B. A. 1981. Effect of thiophanate on epidemic development of anthracnose and yield of watermelon. Phytopathology 71:20-22.

2. Anonymous. 1978. United States Standards for Grades of Watermelons. U. S. Dep. Agric. Agric. Market. Serv. Fed. Reg. Doc. 7735631.

3. Bala, G., and Hosein, F. 1986. Studies on gummy stem blight disease of cucurbits in Trinidad. Trop. Agric. (Trinidad) 63:195-197.

4. Cook, W. P., Keinath, A. P., and Griffin, R. P. 1995. Growing watermelons in South Carolina. Clemson Univ. Ext. Bull. 121.

5. Dow, A. T., Segall, R. H., Hopkins, D. L., and Elmstrom, G. W. 1978. Effects of storage temperature and field fungicide treatments on decay of Florida watermelons. Proc. Fla. State Hortic. Soc. 91:149-150.

6. Duthie, J. A., Shrefler, J. W., Roberts, B. W., and Edelson, J. V. 1999. Plant density-dependent variation in marketable yield, fruit biomass, and marketable fraction in watermelon. Crop Sci. 39:406-412.

7. Everts, K. L., and Shields, P. L. 1999. Evaluation of fungicides for control of gummy stem blight on watermelon. Fungic. Nematic. Tests 54:277.

8. Johnson, C. E., Payne, J. T., and Buckley, J. B. 1995. Evaluation of fungicides for gummy stem blight control on watermelon. Fungic. Nematic. Tests 50:184.

9. Keinath, A. P. 1995. Fungicide timing for optimum management of gummy stem blight epidemics on watermelon. Plant Dis. 79:354358.

10. Keinath, A. P. 2000. Effect of protectant fungicide application schedules on gummy stem blight epidemics and marketable yield of watermelon. Plant Dis. 84:254-260.

11. Keinath, A. P., DuBose, V. B., May, W. H., III, and Latin, R. X. 1998. Comparison of seven fungicide intervals to control gummy stem blight in a fall watermelon crop. Fungic. Nematic. Tests 53:268.

12. Keinath, A. P., and Duthie, J. A. 1998. Yield and quality reductions in watermelon due to anthracnose, gummy stem blight, and black rot. Pages 77-90 in: Recent Research Developments in Plant Pathology. Vol. 2. Research Signpost, Trivandrum, India.

13. Keinath, A. P., and Hassell, R. H. 1999. Evaluation of diploid and triploid watermelon cultivars for field resistance to anthracnose and gummy stem blight. Biol. Cult. Tests $14: 188$.

14. Keinath, A. P., May, W. H., III, and DuBose, V. B. 1997. Comparison of eight fungicide intervals to control gummy stem blight on watermelon. Fungic. Nematic. Tests 52:195.

15. Keinath, A. P., May, W. H., III, and DuBose, V. B. 1998. Comparison of eight fungicide intervals to control gummy stem blight in a spring watermelon crop. Fungic. Nematic. Tests 53:269.

16. Keinath, A. P., May, W. H., III, and DuBose, V. B. 2000. Effect of sequential or alternating applications of Quadris and companion fungicides on watermelon foliar diseases. Fungic. Nematic. Tests. 55:290.

17. Keinath, A. P., and Zitter, T. A. 1998. Resistance to benomyl and thiophanate-methyl in Didymella bryoniae from South Carolina and New York. Plant Dis. 81:479-484.

18. Latin, R. X. 1987. Effect of kind and number of fungicide applications on gummy stem blight of watermelon. Fungic. Nematic. Tests 43:163.

19. Latin, R. X. 1992. Modeling the relationship between Alternaria leaf blight and yield loss in muskmelon. Plant Dis. 76:1013-1017.

20. Latin, R. 1997. Evaluation of fungicides for control of gummy stem blight of watermelon. Fungic. Nematic. Tests 52:196.

21. Latin, R. X., and Evans, K. J. 1996. Development and delivery of a forecaster for Alternaria leaf blight of muskmelon. (Abstr.) Phytopathology 86:S106.

22. Latin, R., Rane, K. K., and Evans, K. J. 1994. Effect of Alternaria leaf blight on soluble solids content of muskmelon. Plant Dis. 78:979-982.

23. Maynard, D. N., and Hopkins, D. L. 1999. Watermelon fruit disorders. HortTechnology 9:155-161.

24. Miller, M. E., Isakeit, T., and Hernandez, R. A. 1998. Evaluation of fungicides for gummy stem blight control on muskmelon. Fungic. Nematic. Tests 53:159.

25. Orton, W. A., and Meier, F. C. 1922. Diseases of watermelons. U. S. Dep. Agric. Farm. Bull. 1277.

26. Patterson, C. L. 1989. Effect of downy mildew (Pseudoperonospora cubensis) on sugar content of watermelon. (Abstr.) Phytopathology 79:1162.

27. Porter, D. R., Bisson, C. S., and Allinger, H. W. 1940. Factors affecting the total soluble solids, reducing sugars, and sucrose in watermelons. Hilgardia 13:31-66.

28. Power, H. J., Jr., coord. 1992. South Carolina 1991 Vegetable Statistics. SC Agric. Exp. Stn. Bull. 472.

29. Suheri, H., and Latin, R. X. 1991. Retention of fungicides for control of Alternaria leaf blight of muskmelon under greenhouse conditions. Plant Dis. 75:1013-1015.

30. Thompson, D. C., and Jenkins, S. F. 1985. Influence of cultivar resistance, initial disease, environment, and fungicide concentration and timing on anthracnose development and yield loss in pickling cucumbers. Phytopathology 75:1422-1427.

31. Timmer, L. W., Zitko, S. E., and Albrigo, L. G. 1998. Split applications of copper fungicides improve control of melanose on grapefruit in Florida. Plant Dis. 82:983-986.

32. van Steekelenburg, N. A. M. 1983. Epidemiological aspects of Didymella bryoniae, the cause of stem and fruit rot of cucumber. Neth. J. Plant Pathol. 89:75-86.

33. Wiant, J. S. 1945. Mycosphaerella black rot of cucurbits. J. Agric. Res. 71:193-213.

34. Young, J. Y., Kirkpatrick, T. L., and Henry, R. N. 1995. Evaluation of fungicide timing and cultural practices for watermelon production. Biol. Cult. Tests. 10:154.

35. Zhang, J. X., Bruton, B. D., Miller, M. E., and Isakeit, T. 1999. Relationship of developmental stage of cantaloupe fruit to black rot susceptibility and enzyme production by $\mathrm{Di}$ dymella bryoniae. Plant Dis. 83:1025-1032.

36. Zitter, T. A. 1996. Black rot. Page 48 in: Compendium of Cucurbit Diseases. T. A. Zitter, D. L. Hopkins, and C. E. Thomas, eds. American Phytopathological Society, St. Paul, MN. 